\title{
15
}

\section{Time Banks in the United Kingdom: An Examination of the Evolution}

\author{
Rodrigo Perez-Vega and Cristina Miguel
}

\section{Introduction}

Sharing economy platforms provide access to other peoples' skills or their time, while others grant access to resources or assets (Wosskow 2014). Sharing initiatives include peer-to-peer lodging and transportation services, time banks, goods exchanges, and other forms of collaboration (Schor et al. 2016). Time banks were created to overcome the dynamics of the commodification of time resources via an alternative system based on reciprocity (Arcidiacono and Podda 2017). The premise of the system is that no one charges for help, 'instead, individuals voluntarily help each other' (Felländer et al. 2015, p. 27). According to

\footnotetext{
R. Perez-Vega

Kent Business School, University of Kent, Chatham, UK

e-mail: r.perez-vega@kent.ac.uk

C. Miguel $(\varangle)$

Applied IT, University of Gothenburg, Gothenburg, Sweden

e-mail: cristina.miguel@ait.gu.se
} 
Whitham and Clarke (2016), a time bank is 'a unique type of generalised exchange that formalises the process of repayment, thus reducing the risk of giving without receiving any benefits in return and the potential for free-riding to occur' (p. 87). There are different models of time banks with diverse aims, and they are implemented in different settings, such as prisons, homeless shelters, schools, and health centres. As observed by Perez-Vega et al. (2021), time banks can be hyperlocal (e.g., Rushey Green Time bank), aimed at serving a particular neighbourhood or community, while others, such as the Economy of Hours, are at the national level. Most time banks include a broad range of services, such as child and older care, car rides, legal services, and gardening (Felländer et al. 2015; Han et al. 2019; Schor et al. 2016). The coordination is done by a central figure called a time bank coordinator or time broker. The time broker minimises the risks of members who directly exchange services (Simon 2004). The Time Online is a time bank software that was created for the brokers to manage the daily exchanges of their time banks (TBUK 2020b).

Teruko Mizushima is widely believed to be the creator of time banking, as he developed and practised it in Japan immediately after the war in 1973. Her time banking revolved around housewives across Japan, and it was called Volunteer Labour Bank (VLB) (Weaver et al. 2016). In the West, time banking originated in the United States in 1955 (Cahn and Grey 2015). Today the United Kingdom (UK) has built a diverse ecosystem around times and skills sharing of both generic (e.g., Time Banking UK, Communities Together) and specialist skills (e.g., Frontline19). For instance, Time Bank is a charity that works across five key themes: social isolation; community cohesion and integration; health and well-being; education and employment; and environmental and regeneration (Time Bank 2020). On the other hand, Frontline19 connects frontline healthcare providers with counsellors and psychotherapists that will provide mental health support for free.

Confusion can be noticed in the spelling of time banking among different parties with the ultimate goal of making their models unique from others. The different spelling formats of time bank include the use of space, a hyphen, and two upper case letters on the two words (Weaver et al. 2016). This chapter will mainly use the term 'time bank' since 
it is the most popular term used in the literature (e.g., North 2003; Seyfang 2004, 2006; Gould 2009; Collom 2012; Válek and Jašíková 2013; Dubois et al. 2014; Arcidiacono and Podda 2017). This chapter aims to define the main characteristics and benefits of time banks. The chapter also provides a typology of platforms that can be found in the UK based on the types of transactions and the types of assets being exchanged (Gerwe and Silva 2020). Later, there is an extensive account of the evolution of time banks in the UK and how the COVID-19 pandemic has fostered the development of new initiatives. Finally, the chapter also provides a discussion of the economic and social impact of time banks as conclusions.

\section{Definitions and Characteristics of Time Banks}

Time banks, according to Schor et al. (2016), are 'multilateral barter service economies that aim to be an alternative to conventional market procurement' (p. 69) where different services can be exchanged at an equal value per hour expended, independently of their market value. For example, an accountant may exchange the time with a cleaner, who may earn a lower hourly rate. Time banks can be defined as rule-based exchange services within a network of community, where the value of services provided is measured in terms of time (hours) as the unit of currency (Weaver et al. 2016). The community network in question could either be a group of individuals, an organisation, or both, where exchange services could either be rendered or received. However, time banks are guided by the egalitarian principle, which supports that the value of time is the same, without minding its actual market value (Seyfang 2001). For instance, one hour of painting is the same as that of babysitting in time banks. Through time banks, those within the community with no financial capacity can also earn similar goods and services by earning the trust of others.

It is noteworthy to state that time banking cannot be regarded as barter; because in barter, there is prior negotiation between the concerned parties, and services may be more valuable than others due to scarcity (Weaver et al. 2016). Unlike time banking, in bartering, there 
is an exchange of services between the parties. Time banks can also not be likened to voluntary work, as the latter is unidirectional, in terms of giving with no intention of receiving, while the former involves elements of reciprocity in its approach, and its members earn credits for all the services rendered. Furthermore, the reflection of the 'bank' in time bank is relative in some countries; for instance, in the US, there is no legal correlation between the two currencies ('time' and money); and in Japan, since 1998, no service exchange can be registered under the name 'time bank', as the term 'bank' is exclusive to financial institutions (Weaver et al. 2016).

Time banks allow people to exchange and trade their skills, an hour for an hour (Wosskow 2014). Indeed, the premise that any type of skill is valuable and the idea that anyone can join is part of the inclusive ideology of time banks. In their study, Schor et al. (2016) found the fact that all contributions are considered equal (the bank is seen as a utopian space of fairness) is one of the main attractions for members. Within time banks, the network of reciprocity is nurtured, thereby creating values for the once untapped resources, skills and making people who had been marginalised to be valuable in the conventional economy (Han et al. 2019). Cahn (2004) affirmed that those who are undervalued and economically irrelevant in society are among those who will likely join time banks because they would have more time available to them. Examples include out of work, carers, the retired, and many others. Interestingly, in their comparative study about different sharing economy platforms, Schor et al. (2016) found that time banks members are overwhelmingly female.

From the economic crisis of 2008, according to Arcidiacono and Podda (2017), time banks are now redefining themselves 'following the logic of the sharing economy' (p. 42), becoming digital time banks. One of the main transformations of time banks because of the digitisation relates to the scalability of the participation from local communities (neighbourhoods and small towns) to global space. In their digital transformation, as observed by Arcidiacono and Podda (2017), time banks have opened up to an unprecedented set of users, increasingly highly educated young people who exchange expertise that is typically more highly skilled and qualified' (p. 43). Nevertheless, these high-skilled 
time bank users often reject time-swap with other members whom they considered lower skilled. In their study, Schor et al. (2016) found that high-skilled members refused to offer certain services such as coding or legal services, 'preferring to exercise a class privilege of confidence and entitlement by trying their hand at manual or creative services' (p. 79). In addition, Schor et al. (2016) observed that some time bank members with high expertise used the time bank just as a place to give charity, 'which allows one-sided trades but does not operate according to the underlying values of the institution' (p. 67). This mismatching ultimately can reduce time exchanges as far as it generates unbalanced accounts. Furthermore, it creates more issues in terms of accessibility and discrimination (Arcidiacono and Podda 2017).

\section{Models of Time Banks}

Over the years, quite a number of rule-based service exchange models have emerged, however not following the egalitarian principle through the exchange of service for goods, money, or other incentives, thus compounding the confusion of the 'original' time bank (Weaver et al. 2016). For instance, the Local Exchange and Trading Systems (LETS) comprises local organisations where people exchange skills through a local currency to equate the actual market value of the exchanged service (Seyfang 2001). According to the New Economics Foundation, the models of time banks can be classified into three: (i) personto-person, (ii) person-to-agency, and (iii) organisation-to-organisation (Ryan-Collins et al. 2008).

\section{Person-to-Person Time Banks}

This is the most common model of time banking where the time broker enquires from the community members of their service needs and the kind of service they can render to other members. The responses of the members are logged into the computer using Time Online to match services offered to those in need. Person-to-person time banking is also 
considered as a low-cost model of volunteering as part of the social care efforts conducted by an organisation, as members can support other community members but also, they can 'buy' support for themselves (Naughton-Doe et al. 2020). It is noteworthy to state that there are two different types of person-to-person time banks, which are communitybased and organisation-based (Ryan-Collins et al. 2008).

The organisation-based or service credit model of person-to-person was developed by Edgar Cahn in the US around the 1980s (Cahn and Barr 1986). With this type of model, the organisation, such as a voluntary agency or public service, was responsible for its hosting, funding, and implementation. A typical example of this model is the Elderplan time bank, which was created in the US by a healthcare provider, with the ultimate goal of providing a reciprocal support network for the aged to live an independent life (Lasker et al. 2011). In the UK, Rushey Green Time bank was established in a General Practitioner (GP) surgery to promote mutual support and improved well-being among patients (Gould 2009). Since the number of time-swappers grown continuously, there is now a distributed model which includes five hubs (Perez-Vega et al. 2021). The ultimate goal of the community-based time banks is to encourage and develop social capital in the community, and its membership is open to anyone interested (Ryan-Collin et al. 2008). A classic example of a non-monetary person-to-person time bank is the time bank Zumbara, launched in Turkey in 2011. According to Subasi and Kirkulak-Uludag (2021), Zumbara is a platform that allows people to earn time in exchange for their service, where people use their know-how, experiences, and talents to support each other.

\section{Person-to-Agency Time Banks}

This model was developed in Wales in 2006, whereby individuals earn credits for volunteering or participating in public services, local agencies, and community groups (Ryan-Collins et al. 2008). In compensation for the service rendered, members of the community could stand the chance of receiving a reward, 'thank you' note, or the opportunity to 
attend leisure activities. Again, this model can either be communitybased or organisation-based. The community-based person-to-agency time banks sought after the development of the community by building a bridge between individuals and local organisation. A typical example is Blaengarw time bank, located in South Wales, where working in the community is rewarded with time currency through the local development agency (NEF 2008). The organisation-based person-to-agency time banks encourage their members to be actively engaged in activities that suit their goals. For instance, residents of the housing association could earn credits for attending residents' meetings (Naughton-Doe 2011).

\section{Organisation-to-Organisation Time Banks}

The organisation-to-organisation model of time bank was launched in London in 2013, and it involves the direct exchange of services, skills, and resources between two organisations (NEF 2008). The ultimate goal of this time bank is to facilitate the exchange of resources among businesses and to build a local network (Ryan-Collins et al. 2008). Services such as room space, marketing, software support, and many others are exchanged.

\section{Benefits and Limitations of Time Banks}

One intended benefit of time banks relates to the co-production of output or services, which can offer additional resources for social care and is perceived as being of higher value than traditional volunteering activities (Evans et al. 2012; Boyle and Bird 2014). Nevertheless, time banks are mainly posited to champion the course of social capital development (North 2003). Social capital can be described as the productive social relationship that occurs between individuals, organisations, and communities (Putnam 2000). Hawkins and Maurer (2012) affirmed that the collaboration between the social network and social support pathway for opportunities, resources, and outcomes for communities, organisations, 
and individuals. Strong ties could be developed as a result of the frequent exchange between members, and there could be possibilities of weak ties among members who are infrequent acquaintances. In addition, time banks can contribute to the development of well-being. Huppert (2009) argued that an individual is said to experience well-being if such a person is contented, resilient and with high esteem. Huppert (2009) identified the five ways to well-being, which include: connect, give, keep active, take notice, and keep learning. Relationships could be built through time banks, where exchanges could further enhance social capital; thus, well-being becomes improved.

Despite the potential for the development of personal relationships and sociability to be established via time banks, many time bankers end up engaging in an instrumental and pragmatic use of time banks, which does not develop into a deeper sociality. As Arcidiacono and Podda (2017) observed, for-profit time bank platforms may prefer this limited sociability because 'when relationships become too recurrent, the users tend to bypass platform brokering, substituting or competing with it' (p. 56). Therefore, this instrumental use (with minimum sociality involved) of time banks seems to question the sharing economy ethos and the ability of time banks to 're-socialise' economic exchange as it seems more similar to the traditional market trade. Indeed, this is in line with other studies (Dubois et al. 2014; Valor and Papaoikonomou 2019), which also found a significant level of homophily within sharing economy transactions (Dubois et al. 2014; Valor and Papaoikonomou 2019). Likewise, Valor and Papaoikonomou (2019), in their study about time banks in Spain and Greece, found that the reason why time banks are often not successful is that they fail to institutionalise the principles of social and market exchange.

One of the potential uses of time banks is community development, as it is believed that communities with strong interaction and relationships often have fewer challenges of poor health, social crimes, unemployment, and many others (Simon 2004). With the help of time banks, communities provide social care for each other through the development of a reciprocal support network of volunteers, and this, in turn, reduces the government's cost of social care. However, some of the intended benefits do not always materialise. For instance, Naughton-Doe et al. (2020) have 
found that the aim of delivering support to communities did not materialise, in particular for low-level activities such as cooking or helping with shopping. Naughton-Doe et al. (2020), in their study of time banks in England, also pointed out that often these aims were not achieved as vulnerable members needed additional protection or support, which led to lower or non-existent levels of co-production. In addition, despite the ethos of time banks as member-led activities, evidence has found that often times, the brokers were the ones with the sole responsibility of facilitating the exchange and defining the rules from which exchanges were implemented (Naughton-Doe et al. 2020). Finally, the level of resources needed to organise these activities was generally high, and usually, there were low levels of engagement from community members, which led to many requests unfulfilled (Dentzer 2001).

\section{A Historical Overview of Time Banks in the UK}

The introduction and emergence of time banks in the UK were in 1998, through the effort of Martin Simon and David Boyle (Simon 2004). It is noteworthy to state that the duo had different interests. For instance, Martin is a community organiser who sees the time bank as an innovative tool for community development (Simon 2004). Simon (2004) went ahead to the first-time bank called Stonehouse Fairshares. David, on the other hand, sees the time bank as an avenue to expand the frontier in the co-production of public services (Simon 2004). Indeed, there are two models of time banking in the UK due to the different perspectives of the two originators-community time bank and time bank that is premised on existing services. Although the motives of the originators of the time bank in the UK might be different, ultimately, the beneficiaries of these initiatives are those who are socially excluded and those who use public services (DHSC 2019).

Thereafter, time banks adopted the organisational structure of formal settings in an attempt to comply with the legislation binding working with vulnerable people in the UK. In the Rushey Green Time bank, based in London, time is banked and swapped (i.e., there is no voucher system). This bank's funding model is based on support from the local 
authorities and other grants (Perez-Vega et al. 2021). This type of time bank is usually funded by councils, community regeneration projects, or charity grants. On the recommendation of Cahn (2004), who posited that for the sustainability of time banking, it must be integrated into councils or services to make it eligible for funding from the public sector. Another typical example of a community-based time bank located in Glasgow is Gorballs Time bank, which promotes social inclusiveness in a diverse community (Seyfang 2004). On the other hand, there are time banks about arts and creativity, such as Leeds Creative Time bank, which was established in 2010 with Arts Council England funding to research informal exchange cultures (Leeds Creative Time bank 2020a). Leeds Creative Time bank employs a non-monetary form of exchange (time credits) and fosters creative activity, from creative writing to sound art and visual arts (Leeds Creative Time bank 2020b), thus providing a rich model for community building (Briggs et al. 2015).

In 2002, Time banking UK (TBUK) was founded by Martin to function as a national umbrella that would coordinate time banking activities. TBUK is not a new time bank, but it welcomes the public sector and individual time banks to join, and it offers both training and operational support for them. In addition, TBUK promotes the activities of time banks to potential funders, and it lobbies on behalf of time banks among the policy community (TBUK 2020a). Time banking UK is an organisation that coordinates many of the time banking activities happening in the country. According to their own statistics, at the time of writing, the organisation had coordinated 278 time banks and facilitated the exchange of 5.6 million hours (Time banking UK 2020).

Some of the time banking organisations in the UK have made attempts to measure the social return on investment on some of their time banking activities. A common measurement used among time banks to assess the impact of their activities is the HACT Social Value methodology (HACT 2018). The methodology provides an assessment of social impact, providing evidence of value for money, and compare the impact of different programmes (Fujiwara 2014). A few time banks have adopted this measurement to assess the impact of their activity. For example, a study conducted by the Barnet time bank found that outcomes related to volunteering and civic engagement, community 
and neighbourhood, health and well-being, and employment and access to services could be identified from the operations of this time bank. The study found that the outcomes measurement using the HACT Social Value methodology showed that the initiative generated $\mathfrak{£ 5 1 8 , 2 5 1}$ through the outcomes being measured over a period of three years (Time banking UK 2017). Since the initiative required an investment of

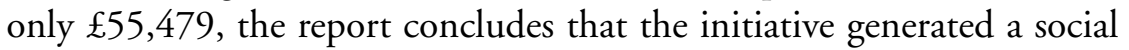
return of investment for every $£ 1$ spent of $£ 9.34$ of social value.

The COVID-19 pandemic impacted several initiatives as face-to-face interaction was significantly reduced as part of the efforts to reduce the spread of the virus (Cabinet Office 2020). However, as self-isolation also had an impact on the well-being and mental health of vulnerable people, initiatives started to appear in the country. For example, Time banking UK, in partnership with Made Open, launched a free national emergency platform called Communities Together. The platform aimed to facilitate the exchange of offers and requests between people in communities to help people who were self-isolating access support and stay connected during this time of crisis (Communities Together 2020). The platform allowed people to exchange general tasks such as walking dogs, helping vulnerable people do their shopping, and organising other forms of assistance. There were also other more specialist initiatives that were involved in the exchange of time, such as Frontline19. Frontline19 is an independent UK nationwide service delivering psychological support where counsellors and other mental health professionals could offer therapy hours free of charge to those who are or have been on the frontline of COVID-19 which many of them were also volunteering their time to support others during the pandemic (Fronline19 2020).

\section{Summary}

Time banks have emerged as a manifestation of the sharing economy where participants can exchange skills and time with one another. In the UK, the time banks began as community-led initiatives, and the country is now a host of over 200-time banks (Time banking UK 2020). The UK Government has been involved in promoting and supporting 
time banks across the country, as the government perceives time banks as being vehicles of social care and inclusion of marginalised communities. However, there is still contesting evidence whether the aims of time banks are, in fact, achieved. Some effort to assess the social impact of time banks in the communities where they operate has led to new methodological approaches, such as the HACT scale, and early evidence seems to suggest that they can benefit the communities where they operate and the participants of time banks (Time banking UK 2017). The COVID-19 pandemic has also forced time banks to rethink their delivery model. Initially, time banks were restricted in their operation as face-to-face interaction was reduced during the lockdown and the subsequent tiered system implemented by the UK Government (DHSC 2020). However, as the pandemic highlighted the need to support the most vulnerable, time banks adapted to their new environment and with the help of technology, they were able to resume their supporting role and organise the exchange of skills and time to serve as support during these unprecedented times.

Future research directions involve both methodological and theoretical developments in the implementation of time banks. From a methodological perspective, simplified scales that can assess the (social) impact and return of investment of time banks initiatives would make their assessment more accessible to smaller time banks. Currently, the HACT scale involves over 122 items, which makes the measurement both time consuming for the respondent, and resource-consuming for the time bank organisers. From a theoretical perspective, a typology of time banks has been developed, but there is a gap on how to overcome the engagement hinderers identified in the current literature (Collom 2007). Research on what mechanisms could drive participant engagement, in particular from the segments that the government is trying to benefit the most, would provide not only theoretical advancements in this manifestation of the sharing economy but would also have a wider impact on improving the quality of life of those participating in this activity. 


\section{References}

Arcidiacono, Davide, and Antonello Podda. 2017. 'Sharing Time: New Forms of Reciprocity in the Digital Economy.' Work Organisation, Labour and Globalisation 11 (2): 39-58. https://doi.org/10.13169/workorgalaboglob. 11.2.0039.

Bird, Sarah, and David Boyle. 2014. Give and Take: How Timebanking Is Transforming Healthcare. Timebanking, UK.

Briggs, Jo, Celia Lury, and Sarah Teasley. 2015. Creative Temporal Costings: A Proto-Publics Research Project with Leeds Creative Timebank. Accessed March 3, 2021. https://researchonline.rca.ac.uk/2220/1/Teasley\%20Creative\%20T emporal\%20Costings\%202015.pdf.

Cabinet Office. 2020. Guidance: New National Restrictions from 5 November (2020). Accessed November 30, 2020. https://www.gov.uk/guidance/ new-national-restrictions-from-5-november?priority-taxon=774cee22-d89644c1-a611-e3109cce8eae.

Cahn, Edgar S. 2004. No More Throw-Away People: The Co-production Imperative. Washington, DC: Essential Books.

Cahn, Edgar, and Christine Gray. 2015. The Time Bank Solution. Accessed March 15, 2021. https://ssir.org/articles/entry/the_time_bank_solution.

Cahn, Edgar S., and Nicholas Barr. 1986. Service Credits: A New Currency for the Welfare State. Welfare State Programme Discussion Papers (WSP 008). Centre for Analysis of Social Exclusion, The London School of Economics and Political Science, London, UK.

Collom, Ed. 2007. 'The Motivations, Engagement, Satisfaction, Outcomes, and Demographics of Time Bank Participants: Survey Findings from a US System.' International Journal of Community Currency Research 11 (1): 3683. https://doi.org/10.15133/j.ijccr.2007.004.

Collom, Ed. 2012. 'Key Indicators of Time Bank Participation: Using Transaction Data for Evaluation.' International Journal of Community Currency Research 16 (A): 18-29. https://doi.org/10.15133/j.ijccr.2012.002.

Communities Together. 2020. About. Accessed November 24, 2020. https:// together.madeopen.co.uk/about.

Dentzer, Susan. 2001. 'Service Credit Banking.' In To Improve Health and Health Care, edited by S. Isaacs and J. Knickman, 1-23. Washington, DC: Robert Wood Johnson Foundation, San Francisco: Jossey-Bass. 
DHSC (Department of Health and Social Care). 2019. 'The NHS Long Term Plan.' The British Medical Journal 364 (January): 1-2. https://doi.org/10. 1136/bmj.184.

DHSC (Department of Health and Social Care). 2020. Local Restriction Tiers: What You Need to Know. Accessed December 3, 2020. https://www.gov.uk/ guidance/local-restriction-tiers-what-you-need-to-know.

Dubois, Emilie A., Juliet B. Schor, and Lindsey B. Carfagna. 2014. 'New Cultures of Connection in a Boston Time Bank.' In Sustainable Lifestyles and the Quest for Plenitude: Case Studies of the New Economy, edited by J. B. Schor and C. J. Thompson, 95-124. New Haven, CT: Yale University Press.

Evans, Simon, Sarah Hills, and Judy Orme. 2012. 'Doing More for Less? Developing Sustainable Systems of Social Care in the Context of Climate Change and Public Spending Cuts.' British Journal of Social Work 42 (4): 744-764. https://doi.org/10.1093/bjsw/bcr108.

Felländer, Anna, Claire Ingram, and Robin Teigland. 2015. 'Sharing Economy.' In Embracing Change with Caution. Näringspolitiskt Forum Rapport, no. 11. 2015. Accessed May 27, 2021. https://www.academia.edu/download/ 37923227/Sharing-Economy_webb.pdf.

Fronline19. 2020. About. Accessed November 11, 2020. https://www.frontl ine19.com/therapists/.

Fujiwara, Daniel. 2014. Measuring the Social Impact of Community Investment: The Methodology Paper. HACT Ideas and Innovation in Housing. Accessed March 15, 2021. https://hact.org.uk/sites/default/files/uploads/Arc hives/2014/3/HACT\%20Methodology\%20Paper\%20FINAL.pdf.

Gerwe, Oksana, and Rosario Silva. 2020. 'Clarifying the Sharing Economy: Conceptualization, Typology, Antecedents, and Effects.' Academy of Management Perspectives 34 (1): 65-96. https://doi.org/10.5465/amp.2017.0010.

Gould, Vanessa. 2009. Lewisham Time Bank Development Strategy 2009-2012. London: NHS Lewisham.

Han, Kyungsik, Patrick Shih, Victoria Bellotti, and John Carroll. 2019. 'It's Time There Was an App for 30 That Too: A Usability Study of Mobile Timebanking.' International Journal of Mobile Human Computer Interaction 7 (2): 1-22. https://doi.org/10.4018/ijmhci.2015040101.

Hawkins, Robert L., and Katherine Maurer. 2012. 'Unravelling Social Capital: Disentangling a Concept for Social Work.' British Journal of Social Work 42 (2): 353-370. https://doi.org/10.1093/bjsw/bcr056.

Housing Associations' Charitable Trust (HACT). 2018. Value Calculator. Accessed November 24, 2020. https://www.hact.org.uk/value-calculator. 
Huppert, Felicia A. 2009. 'Psychological Well-Being: Evidence Regarding Its Causes and Consequences.' Applied Psychology: Health and Well-Being 1 (2): 137-164. https://doi.org/10.1111/j.1758-0854.2009.01008.x.

Lasker, Judith, Ed Collom, Tara Bealer, Erin Niclaus, Jessica Young Keefe, Zane Kratzer, Lauren Baldasari et al. 2011. 'Time Banking and Health: The Role of a Community Currency Organization in Enhancing Well-Being.' Health Promotion Practice 12 (1): 102-115. https://doi.org/10.1177/152483 9909353022.

Leeds Creative Timebank. 2020a. About Leeds Creative Timebank. Accessed March 15, 2021. https://leedscreativetimebank.org.uk/about/.

Leeds Creative Timebank. 2020b. Skills List. Accessed March 15, 2021. https:// leedscreativetimebank.org.uk/people-skills/skills-list/.

Naughton-Doe, Ruth. 2011. 'Time Banking in Social Housing: A Toolkit for Co-production in Public Services.' International Journal of Community Currency Research 15: 71-68. https://doi.org/10.15133/j.ijccr.2011.025.

Naughton-Doe, Ruth, Ailsa Cameron, and John Carpenter. 2020. 'Timebanking and the Co-production of Preventive Social Care with Adults; What Can We Learn from the Challenges of Implementing Person-to-Person Timebanks in England?' Health \& Social Care in the Community 1 (9): 1-11. https://doi.org/10.1111/hsc.13166.

New Economics Foundation (NEF). 2008. The New Wealth of Time: How Timebanking Helps People Build Better Public Services. Accessed October 3, 2020. https://nwi.pdx.edu/webinars/Webinar13-materials1.pdf.

North, Peter. 2003 'Time Banks_Learning the Lessons from LETS?' Local Economy 18 (3): 267-270. https://doi.org/10.1080/026909403200011 1048.

Perez-Vega, Rodrigo, Brian Jones, Penny Travlou, and Cristina Miguel. 2021. 'United Kingdom: An Examination of the Configuration of the Sharing Economy, Pressing Issues, and Research Directions.' In The Collaborative Economy in Action: European Perspectives, edited by Andrzej Klimczuk, Vida Česnuityte, and Gabriela Avram. Limerick, Ireland: University of Limerick. Putnam, Robert D. 2000. 'Bowling Alone: America's Declining Social Capital.' In Culture and politics, 223-234. New York: Palgrave Macmillan.

Ryan-Collins, Josh, Lucie Stephens, and Anna Coote. 2008. The New Wealth of Time: How Timebanking Helps People Build Better Public Services. London: New Economics Foundation.

Schor, Juliet B., Connor Fitzmaurice, Lindsey B. Carfagna, Will AttwoodCharles, and Emilie Dubois Poteat. 2016. 'Paradoxes of Openness and 
Distinction in the Sharing Economy.' Poetics 54: 66-81. https://doi.org/ 10.1016/j.poetic.2015.11.001.

Seyfang, Gill. 2001. 'Working for the Fenland Dollar: An Evaluation of Local Exchange Trading Schemes as an Informal Employment Strategy to Tackle Social Exclusion.' Work, Employment and Society 15 (3): 581-593. https:// doi.org/10.1177/09500170122119165.

Seyfang, Gill. 2004. 'Time Banks: Rewarding Community Self-Help in the Inner City?' Community Development Journal 39 (1): 62-71. https://doi. org/10.1093/cdj/39.1.62.

Seyfang, Gill. 2006. 'Harnessing the Potential of the Social Economy? Time Banks and UK Public Policy.' International Journal of Sociology and Social Policy. https://doi.org/10.1108/01443330610690569.

Simon, Martin. 2004. On Becoming a Time Broker. Gloucester: Fairshares.

Subasi, Ozge, and Berna Kirkulak-Uludag. 2021. 'A Socially Engaged Model of Sharing Platforms in Turkey: Design as a Blueprint of Practices and Local Cooperations.' In The Collaborative Economy in Action: European Perspectives, edited by Andrzej Klimczuk, Vida Česnuityte, and Gabriela Avram. Limerick, Ireland: University of Limerick.

Time Banking United Kingdom (TBUK). 2020a. About TBUK. Accessed October 3, 2020. https://www.timebanking.org/about-tbuk/.

Time Banking United Kingdom (TBUK). 2020b. Time Online 2 Unleashed. Accessed October 3, 2020. https://www.timebanking.org/time-online-2-unl eashed/.

Timebanking United Kingdom (TBUK). 2017. Calculating the Social Value of Person to Person Timebanking. Accessed November 24, 2020. https://www.timebanking.org/wordpress/wp-content/uploads/2011/ 09/Barnet-SROI-impact-report-2017.pdf.

TimeBank. 2020. Who We Are. Accessed October 3, 2020. https://timebank. org.uk/about/who-we-are/.

Válek, Lukáš, and Veronika Jašíková. 2013. 'Time Bank and Sustainability: The Permaculture Approach.' Procedia-Social and Behavioral Sciences 92: 986991. https://doi.org/10.1016/j.sbspro.2013.08.788.

Valor, Carmen, and Eleni Papaoikonomou. 2019. Sharing Economy to the Rescue? The Case of Timebanking. In Handbook of the Sharing Economy, edited by R. Belk, G. Eckhardt, and F. Bardhi, 136-152. Cheltenham, UK: Edward Elgar Publishing.

Weaver, Paul, Adina Dumitru, Ricardo García-Mira, Isabel Lema, Loes Muijsers, and Veronique Vasseur. 2016. Transformative Social Innovation Report: Timebanking. TRANSIT: EU SSH.2013.3.2-1 Grant agreement 
no: 613169. Accessed March 15, 2021. http://www.transitsocialinnovation. eu/content/original/Book\%20covers/Local\%20PDFs/253\%20Time\%20B anks\%20-\%20Case\%20study\%20report\%20Time\%20Banks-2017.pdf.

Whitham, Monica M., and Hannah Clarke. 2016. 'Getting Is Giving: Time Banking as Formalized Generalized Exchange.' Sociology Compass 10 (1): 87-97. https://doi.org/10.1111/soc4.12343.

Wosskow, Debie. 2014. Unlocking the Sharing Economy: An Independent Review. Department for Business, Innovation and Skills. Accessed May 27, 2021. Available at: https://assets.publishing.service.gov.uk/government/upl oads/system/uploads/attachment_data/file/378291/bis-14-1227-unlockingthe-sharing-economy-an-independent-review.pdf.

\section{Suggested Readings}

Ottlewski, Lydia. 2021. Platforms for Social Innovation. Thesis. University of St Gallen. Accessed March 15, 2021. https://www.alexandria.unisg.ch/262 $414 /$.

Pill, Madeleine. 2021. 'Neighbourhood Collaboration in Co-production: StateResourced Responsiveness or State-Retrenched Responsibilisation?' Policy Studies: In press ahead of publication. https://doi.org/10.1080/01442872. 2021.1892052.

\section{Relevant Websites}

MadeOpen: https://madeopen.co.uk/timebank.

Timebanking UK: https://timebanking.org. 
Open Access This chapter is licensed under the terms of the Creative Commons Attribution 4.0 International License (http://creativecommons.org/ licenses/by/4.0/), which permits use, sharing, adaptation, distribution and reproduction in any medium or format, as long as you give appropriate credit to the original author(s) and the source, provide a link to the Creative Commons license and indicate if changes were made.

The images or other third party material in this chapter are included in the chapter's Creative Commons license, unless indicated otherwise in a credit line to the material. If material is not included in the chapter's Creative Commons license and your intended use is not permitted by statutory regulation or exceeds the permitted use, you will need to obtain permission directly from the copyright holder.

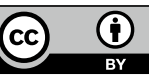

